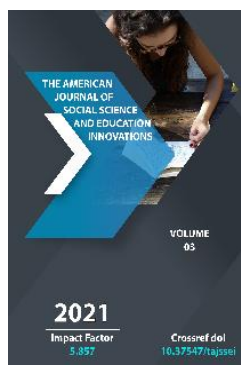

\title{
The Struggle Of Sultan Saidkhan Against Shaybanids In Ferghana Valley
}

\author{
Abdurashid Abdurasulovich Nishonov \\ Doctoral Candidate Of Ferghana State University, Uzbekistan
}

\begin{abstract}
Journal Website: http://usajournalshub.c om/index,php/tajssei

Copyright: Original content from this work may be used under the terms of the creative commons attributes 4.0 licence.
\end{abstract}

\section{ABSTRACT}

The range of sources devoted to the study of the history of the 16th century depicted the struggles for the territories of Ferghana valley. The aim of the present paper is to thoroughly examine the historical data and information about Sheybanids and their reign in the territory of Ferghana valley, and the struggles of Sultans from the historical resources and give the author's assumptions on this matter. The methods as historical-comparative and analytical descriptive have been used while doing research. The results of the research are the inferences of Khaydar and Babur's sources, which reveal the verisimilar description of the events. From the secondary research of literature the author showed the consequences led to the reign of Sheybaniy Sultans in Ferghana valley.

\section{KEYWORDS}

Ferghana valley, Sultan Saidkhan, Babur, “Baburname”, Shaybonikhan, Jonibek Sultan, Sevinchjakhon, "History of Rashidiy", Ahsi, Kosimkhan, "Oshtin Kazak"

\section{INTRODUCTION}

Historical events in the early 16th century in Ferghana Valley were partly described in "Baburnoma" by Zahiriddin Muhammad Babur,
"Shayboniynoma" by Kamoliddin Binoiy,
"Sheyboniynoma" by Muhammad Salih,
"Rashidiy's history" by Mirzo Muhammad 
The American Journal of Social Science and Education Innovations (ISSN - 2689-100x)

Published: April 30, 2021 | Pages: 264-273

Doi : https://doi.org/10.37547/tajssei/Volume03Issue04-40

Haydarniy, "Musahhir al bilod" by Muhammadyor ibn Arab Qataghaniy" and "Abdullanoma" by Khofiz Tanish al-Buhari.

\section{MATERIALS AND METHODS}

The data and information about the history of Fergahana valley can be found in the works by S.Azimjonova "On the History of Fergana of the second half of the XV century", "Lessons from history" by B.Ahmedov, "The army formation and military management in Bukhara khanate" by A.Zamonov, "History of Uzbekistan (XVI-XIX c.)" by D. Alimova, "Babur's State of Ferghana" by S. Jalilov, "Manuscripts of the XVI-XVIII centuries in Ferghana Valley" by Yusupova D, "Ferghana in the Period of Amir Temur's Struggle for power (1360-1370)" by Usmonov B, "A History of inner Asia” by Branko Soucek and Swan Soucek, "The Empire of History of Central Asia" by Rene Grousset and "Fergana during the reign of Sultan Saidkhan" by A.Nishonov. Analyzing the data in the abovementioned sources and literature, we examined the struggle of Sheybanid Sultans and Sultan Saidkhan in the Ferghana Valley.

In the Ferghana Valley, the struggle for power between Zahiriddin Muhammad Babur and Jahongir later had become a controversy between the Temurids and the emirates. As a result of the conflict, the power in the Ferghana Valley was handed over to one of the valley's great rulers, Ahmad Tanbal. After the loss of Samarkand and occupying it by Sheibani Khan, Bobur attempted to regain power in Fergana with the help of his cousins Sultan Mahmud Khan and the Sultan Ahmad Khan. Ahmad Tanbal asks Shaibani Khan to help preserve power in Ferghana. The reign of Ahmad Tanbal, who ruled in Fergana with the help of Sheibani Khan, did not last long, and the Sheibani Khan was established in Ferghana
Valley. As in Movarounnahr, the Sheybanid dynasty ruled in Ferghana Valley for a short period, which is due to the name of Sultan Said Khan.

\section{The short history of the reign of Sultan Saidkhan.}

Sultan Saidkhan was the son of Sultan Ahmad Khan, the uncle of Babur's grandson. Sultan Ahmed Khan had eighteen sons, Sultan Said khan was the third son after Mansur Khan and Iskander Sultan. In 1503 Sultan Ahmad Khan came with a large army from Mongolia to assist his brother Sultan Mahmud Khan, the governor of Tashkent, against the Sheibani Khan. He put his eldest son Mansurkhan on the throne of Mongolia and brought his two sons Sultan Saidkhan and Babajok Sultans to Tashkent. Zakhiriddin Muhammad Babur in his "Baburnoma" noted that he was fourteen when he met Sultan Saidkhan in Tashkent [6: 96b]. Two khans and the troops of Babur alliance were defeated in the battle with Sheibani Khan near Ahsi. Sultan Said Khan, who took part in the battle, was wounded and captured by the governor of Ahsi Sheikh Bayazid. Sheikh Bayazid kept Sultan Saidkhan in prison for one year. In 1504, Sheibani Khan captured Ferghana Valley by walking against Ahmad Tanbal and his siblings in Fergana. Sheibani Khan ordered the execution of Ahmed Tanbal and his family who had betrayed $\operatorname{him}[4: 245$ - b].

After the conquering of Fergana Valley, Sheibani Khan gave the area to Jonibek Sultan. Muhammadyar ibn Arab Qataghan stated in his work "Musakhhir al-Bilad" that Andijan was handed over to Mahmudshoh Sultan, and Ahsi to Sultan Jonibek [2: 88b]. However, it is known from the works of Muhammad Salih and Haydar that Ferghana Valley was 
completely donated to Jonibek Sultan [4: 245; 3: 243]. Jonibek Sultan was the cousin of the uncle of Shaybanban Khan Hoja Muhammad Sultan [11: 142].

Jonibek sent Sultan Said Khan, who was imprisoned in Sultan Ahsi, to Sheibani Khan. We learn that Sheibani Khan accompanied Sultan Saidkhan while he was near Termez when he said that his brother Mahmud Sultan died in Kunduz. Mahmud was surprised to see the Sultan's coffin and his face had not changed. Sultan Said Khan realized that it was very dangerous to stay near Shaybanhan and escaped from Samarkand to Mongolia through the Hutuk route [3: 261].

Sultan Mahmud Khan, who was defeated by Sheibani, came to Mongolia and took over power in Mongolia after the death of Sultan Ahmad Khan. The arrival of Sultan Said Khan to Mongolia was a threat to Sultan Mahmud Khan's rule. Sultan Mahmudhon began the fights against Sultan Said Khan, fearing that he would claim his throne. Sultan Saidkhan, who was defeated in the fight, went to his brother Sultan Khalil, who headed the Kyrgyz.

\section{The struggles between the Sultns.}

Between 1504 and 1509, the war between the Mongol khanates and the prince in Mongolia intensified. Sultan Mahmudkhon, who was defeated in battle, went to Sheibani Khan. Sheibani Khan killed him. In 1509, Mansur Khan, who took power, marched upon his brothers Sultan Said Khan and Sultan Khalil. The battle between the brothers took place in Almaty [3: 262]. Sultan Khalil, who was defeated in the battle, fled to Fergana in the hope of being sponsored by Shaybankhan. At Ahsi, Jonibek Sultan seized him and drowned him in the Ahsi river. After the defeat in Almaty, Sultan
Saidkhan came to Dolan with about fifty survived people.

In Dolan the group of people of the ruler of Kashgar Abubakr Mirzo was about to kill him. Escaping from them he followed his uncle and brother and fled to Fergana. Mirzo Khaydar in his work "History of Rashidiy" described this story as follows: "Only a person who does not know the nature of Shahibek Khan can look at it, no matter how many people reject this plan, they have not given up on their brains. I also had hundreds of objections to them, for during the year I spent with Shahibek Khan I had thoroughly studied all his features, the character and intentions of the Sultans and Amirs. I knew what he did and what he could do. No matter how much I told these people, they disagreed, saying, "What else can we do? Any suggestion is nonsense. It is possible to hope for the good. If you have any other ideas in your blessed brain, tell them, for we will obey you with all our heart" [3:271].

When Sultan Said Khan went to Ferghana, Sheibani Sultan Jonibek was the ruler there. Jonibek Sultan granted Andijan to Hoja Ali Bakhodir, one of the trustees of Sheibani Khan.

Sultan Saidkhan, who arrived in Sulatkand, near Andijan in 1508, was aware that his uncle and brother were executed by Sheibanikhan. Khodja Ali Bakhodir captured the Sultan Saidkhan and his men and imprisoned them in Andijan [3: 332].

Jonibek Sultan fell from a horse and was mentally retarded and did not comply with what he said. Khoja Ali sent a courier to Bakhodir Ahsi and then sent Sultan Said Khan to Jonibek Sultan. When there was a little distance to Ahsi, Khaidar Harsuvar came and said that Jonibek Sultan had freed him and that the order was brought by the lame 
Dusmuhammad Ali. [3: 334] Dusmuhammad Ali told the soldiers who brought Sultan Said Khan about fetching the letter from Jonibek Sultan and ordered to take the captive to Hodja Ali. Sultan Saidkhan was brought back to Andijan by soldiers. Khoja Ali, who had received the letter, said that the brave Sultan Saidkhan was set free and could go wherever he wanted. A day later, Allaberdi brought a decree from Ahsi that ordered Sultan Said Khan to be executed immediately. [3: 335] Khoja Ali Bakhodir disobeyed the orders and put Sultan Said Khan into the Kairat Tegin road. The khan and his companions lost their ways and had to turn back. In Andijan, Hodja Ali Bakhodir held them for a while and then sent them to Mirzokhon to the fortress Zafar. Spending the eighteen days in the fortress Zafar, he returned to his cousin King Babur to Kabul [3: 335].

Sultan Saidkhan was captured twice by the Shaybanids after his father's death and every time he managed to survive, he eventually fled to Kabul to Babur. Academician V.V. Bartold claimed that Sultan Saidkhan came to Babur in 1508. [1: 513] The death of Sheibanikhan in the battle of Isma'il with the Shah of Iran near Merv in 1510 led to the beginning of a struggle against Sheybanikhans in Ferghana Valley. The fact that Jonibek Sultan, who ruled Ferghana Valley during Sheiban-khan [2: 326] in Samarkand, was also a good starting point for this movement. In the early spring of 1511, the Sheybani Sultans assembled in Samarkand, fearing the possible attack of Babur on Maveraunnakhr.

It is known that after the oppressing the rule of Sultan Mahmud Khan in Tashkent and Shahrukhiya by Sheybani Khan, most of the defeated Mongolian troops filled the Sheybanid army. When Sheibanikhan died, some of them passed to the side of Babur, the grandson of the great Mongolian Khan Yunuskhan. This causes distrust of Sheyban Sultans against the mongols. As a result, they began to invade the Mongols. Most of the surviving Mongols fled to Babur, and some fled to Ferghana Valley, where their families lived. Said Mohammed, one of the Mongol emirs, who succeeded to return to Ferghana Valley with the permission of Sultan Jonibek, later led the fight against the Sheybanids in the valley. [3: 317] Haydar also quoted the message from Ferghana: "The Ferghana region is completely free of Uzbeks and it is in your favor that this is the end of Uzbeks' work and the beginning of the liberation of Movarounnahr. So we will do what you say"[ 3: 355].

\section{Changing the situation in the valley.}

In his work, Babur refers to the uprising revolt against the Sheybanians in Ferghana Valley, who ignored the Mongol presence. "When I took over Shah Ismail Shaibanikhon in Merv," wrote Bobur, "Andijan region was looking at me, digging some gates, closing some areas and sending the army against mea. I gave Sultan Saidkhan all my duty and gave Andijan region to him [5: 180-b]. The reasons for this sending are probably connected with the fact that the Mongols led the riots in the valley.

By that time Babur's largest part of the army consisted of the Mongolian soldiers, and the fact that the Mongol prince Sultan Saidkhon served him under these conditions was causing some political instability. [3: 358-b] The second reason why Babur decided to send Sultan Said Khan to Ferghana Valley could be further explained. With this decision, Babur managed to draw the attention of the Sheybanites to Ferghana Valley. He was also able to maintain stability in his own country. 
According to Khaydar Mirza, Sultan Saidkhan on May 13, 1511, departed from Mirza Babur and headed for Fergana Valley. As it can be seen, the actions against Sheybanians in Ferghana Valley began in March-April 1511 and had some results. With the arrival of Sultan Saidkhan, his reign woupl be established throughout the valley. V, V. Bartold also states that Sultan Saidkhan was sent to Ferghana Valley by Babur in 1511 [1: 5120].

It is known that in March-April 1511 Babur also began to march towards Gissar [3: 359]. It is likely that the march of Bobur led to the beginning of the movement in Ferghana. Although Hafiz Tanish Bukhari and Muhammadyor ibn Arab Kagan did not mention this in their writings [2: 326], according to the version of Khaidar, this Babur's march ended in vain and he returned [3: 354]. As a result, the Shaybanids split their forces into three. The army led by Hamza Sultan, Mahdi Sultan and the son of Shaibanikhon Sultan headed for Hisor against Babur, while Ubaydullahan decided to stay in Karshi and defend the center of Movarounnahr from the south. Jonibek Sultan was also fighting with several Sheybani Sultans to take back Ferghana Valley. The Sheibanids initially decided to invade the northern part of Syrdarya.

This is probably due to the administrative and military position of the Ahsi fort in the north of the Syrdarya, for during the SheibaniKhan rgein the city of Ahsi again became an administrative center of the valley. Historical records indicate that the Sultan ruled Ferghana Valley from the city of Ahsi [2: 91]. Indeed, it is natural that he had taken steps to strengthen the defense capability of his administrative center. That is why Jonibek Sultan's goal was to gain the capital of his estate as soon as possible.

The Sheybanids initially decided to ocupy Koson from the fortresses in the north of Syrdarya. When their troops failed to invade the fortress of Kasan, they began to lay siege to it. The castle guards, led by Sultan Ali Mirza and Tubra Nuyagut, fought bravely. Sultan Saidkhan's efforts to support the fortresses have been successful, albeit small. "When the news of the fortress of Koson reached the khan," wrote Khaidar, he sent all the commanders to the Kasan Mountains. Although they did not have the power to intimidate the Uzbeks, they attacked some of the enemy's wings and disturbed them, and the Kosan people were much more encouraged by it". The fate of the battle could be decided by the actions of the Sheybanians to capture the fortress. Sources say that the attacking party pierced the Koson fortress walls and climbed it up the stairs. The guards then left the castle. In our opinion, the events that took place in the Far East of Ferghana Valley were also greatly influenced on the surrendering the castle.

During the fierce battles for Kasan, the governor of Kashghar Abobakr also raided the eastern part of Ferghana Valley. This was his second attempt to conquer Ferghana Valley, the first of which was when Umarshaykh died [3: 363]. Abobakr, who effectively utilized all forces against the Sheybanians, easily conquered the fortresses of Uzgen, Osh and Modu. The Haydar memoirs said that Abobakr had come with an army of only two or three thousand people. [3: 364] But this information is a bit questionable. This is evidenced by the fact from Khaydar's scriptures that three important fortresses were occupied, as well as 
the fact that there left about three thousand captives.

The Kashghar army, which occupies three fortresses in the east of the valley, was also planning to invade Andijan. Located $3-4 \mathrm{~km}$ from Andizhan, the Kashgars were seriously preparing to invade the castle. Sultan Said Khan also decided to immediately withdraw his troops in Kosan. However, the victories of Abobakr and his serious preparations for the conquest of Andijan had caused a great deal of panic among the people of the valley and Sultan Said Khan's palace. Speaking about the perfect armor of the Kashghar army, Khaydar said: When news of this reached Sultan Said Khan, he and the people of Andijan were terrified"'[3: 364].

However, the arrival of the army, which fought for Koson, for the protection of Andijan changed the situation. The forces that came to the aid were so great that the Ferghana troops dared to leave the city to defend the Andijan fortress. During the fight near Andijan, Kashgar troops were completely defeated. The cities of Osh, Uzgen and Modu Castle were also released from the Abobakr occupation. That victory had a profound effect on the political and military situation in Ferghana Valley.

The Sheybanids who occupied the Kosan fortress did not dare to continue their march. After the victory, Sultan Said Khan himself and the majority of the army moved to the Ahsi fortress, near Koson, where the Sheybanids' army was located. Haydar's memoir also stated in his "History of Rashidiy" that Sultan Saidkhan left Said Muhammad in Andijan and went to Ahsi. [3: 383] Soon after, Bobur reported that his army took over Shaybonid Sultans troops in Hisar. Under the influence of this message, the Sheybanid army in the valley decided to retreat. As a result, the rule of Sheybanids was temporarily restricted in Ferghana Valley, and by the summer of 1511 the power was completely transferred to Sultan Said Khan.

\section{Sheybanid's rule}

The Sultan Said Khan state, established in Ferghana, recognized the supreme authority of the ruler of Samarkand, Babur. Khaydar mirzo also said that when Sultan Said Khan was fortified in Ferghana Valley, Said Muhammad, the organizer of the Sheybanid struggle in the valley, had sent Mirza to the ambassador to Samarkand to Babur. According to the author, the embassy took place in the winter of 15111512, when important state affairs were resolved. It can be argued that the main focus of these government affairs is to continue to fight together against the Shaybanids. Bobur wrote his memoirs about this embassy in his work "Boburnoma". [5:13]

In the spring of 1512, the Sheybanid Sultans began to move towards Bukhara and Tashkent. Bobur set out for Bukhara with a pert of the army, and another army led by Amir Qasim was sent to defend Tashkent. However, in the Battle of Lake Malik to the west of Bukhara, Babur's army was completely defeated. Bobur first decided to move to Samarkand and then to Gissar. There is no historical record of the extent to which Ferghana Valley Governor Sultan Saidkhan was involved in these events. The author of the book "History of Rashidiy" detailing the defensive fights carried out by Emir of Qosim Amir in Tashkent did not tell about Sultan Saidkhan's support. It appears that Sultan Saidkhan was limited to observing these events. That was his biggest mistake, which later led to his demise. Tashkent defenders left the city and fled to Ferghana 
Valley. They preferred to stay in Sultan Saidkhan's palace and visit Babur, who was rebuilding his forces in Gissar.

It was expected that Sheybanids who occupied Tashkent would continue their march to Ferghana Valley. But some events did not create the opportunities for it. First, Amir Kattabek, appointed by Babur's governor as hakim (mayor) of Sayram, held the fort until the spring of 1513. [3:389] Second, Babur, who had been reviving itself at Gissar at that time, was expected to once again begin to attack the Sheybanians, relying on the help of King Ismail. In these circumstances, the Sheybanids who invaded Tashkent had to wait for the situation to develop.

The name of Sevinchkhojakhan, who conquered Tashkent, was not mentioned in the ranks of Sheybanid Sultans who fought against the succession of Babur's army with the Iranian army commander Amir Najm. Although this was not mentioned in other historical sources, the information in the "History of Rashidiy" was well-grounded.

Sultan Saidkhan began to attack the Sheybanids because of the standstill of Sheybanids' occupation of Tashkent and at the request of Babur Mirza. Sources say that even when Babur was in Gissar, ambassadors were exchanged with Sultan Saidkhan. Therefore, it is possible to say that the Ferghana army's attack on Shaybanids was done by mutual agreement.

According to the "History of Rashidiy", the battle between Sultan Said Khan and the army of Sevinchkhoja was in Biskand, [3: 383] which must be presently the city of Piskent in the territory of the present Tashkent region. It is well known that one of the historical sources of that time the name of this place in various copies of the Baburnoma was given by Piskent and Beshkent, and in their translations as Biskand. [5: 88] The Biskand area can also be a place where there was a battle. In this case we can conclude that Sultan Saidkhan entered the Tashkent not through a mountain pass, but through Khujand.

The Biskand battle was won by Sheybanids. Sultan Said Khan, wounded in the battle, returned to the valley and had to wait for the outcome of the battles of Babur. The Biskand battle took place in September 1512 or shortly thereafter. Because on that very day, Haidar mirzo, who had come to Sultan Said Khan, claimed that he had returned from the battle of Biskand [3:38].

Sevinchhojakhan also did not dare invade Sultan Said Khan. As it was mentioned earlier, Sayram was not captured and Babur's battle in Karshi oasis probably should have been the reason for this.

On November 12, 1512, Babur and the Iran commander Najm soniy were completely defeated by Sheybanians near the city of Gijduvan [2: 126]. After leaving Gijduvan to Gissar, Babur returned to Kabul shortly afterwards. This meant that he had completely abandoned Movarounnahr.

In this situation, Sultan Saidkhan tried to keep his state as much as possible. It should be noted that the foreign policy situation had also helped him. Fearing that King Ishmael would revenge for the death of Amir Najm soniy, Sheybanites had to keep most of his troops on the border with Iran. In the spring of 1513, Amir Kattabek, who had kept Sayram, handed him over not to Sheibani, but to their fierce rival, the Kazak khan, Kosimkhan [3:391]. In the result of it, The Kazaks had a serious threat on 
the properties and lands of Sheybanites in Turkiton and Tashkent.

But before that, after the defeat of Babur, the Sevinchkhojakhan began to march to Ferghana Valley. Since Khaydarzo mirzo said that Sevinchkhojakhan's march took the place three months after the battle of Biskand, we can set the march for the end of November and December 1512. This Sevinchkhojakhan's did not end. This was mainly due to the defensive plan implemented by Sultan Said Khan. He left the army under the leadership of Mir Guri Barlos in Ahsi, Mir-Doim Ali in Margilan, and Said Muhammad in Andijan, and retreated to the mountains in northern Andijan [3: 388, 389]. Sevinchkhojakhan stopped marching and had to go back due to the winter, the severe situation in the north and the impossibilities of laying the siege the cities of the valley.

Taking advantage of this, Sultan Saidkhan also decided to pursue an aggressive policy. In the spring of 1513 he attacked Ahangaran district of Tashkent region. The Ferghana army was victorious in several small battles. Khaydar noted that Sultan Saidkhan displayed special heroism in the fighting, noting that he personally took part in the march [3:390]. The Ferghana troops did not dare go to Tashkent and went back to the valley with great trophy.

As we have already seen, in the spring of 1513, the Kazakh khan, who oewned Sayram, went to Tashkent at the request of emir Kattabek, who gifted Sayram a little later. Although he did not conquer Tashkent, he returned to the Kazakh steppes after surrounding Sevinchkhoja for a while and looting.

Having learned about Kasimkhan's march in Tashkent, Sultan Saidkhan once again began to walk on Sevinchkhojakhan. The was warned about Kasimkhan going back when Ferghana army reached the Kandirlik oasis between Tashkent oasis and Ferghana Valley. As a result, Sultan Said Khan decided to stop marching.

\section{Surrendering Ferghana valley by Saidkhan}

In the summer of 1513, Sultan Saidkhan fortified the fortresses of Ferghana Valley and traveled through Mongolia to Kasimkhan. Academician V.V. Bartold noted that Kasimkhan and Sultan Saidkhan had the meeting in the autumn of 1513 at the Chu River. However, his talks with Kasym Khan were in vain. The Kazakh khan refused to go against Shaybanids. Khaidar reported about this: "Summer is over. By the order of Kasymkhan, the Kazakhs moved to stay winter. "It's hard to go against Shayban now. Nowadays, it is better for people to take care of winter. At this time, the troops will not be assembled", Kasimkhan said. In the same way he refused to walk gently and politely. Kasymkhan kept the Khan's esteem and moved to his native place. The Saidkhan returned with pleasure and went to Andijan. One of the scholars of the palace had made a history of this event with the words "Ashtin kazak" ("Peace with the Kazakhs"), the collection of the letters in the word denoted the years 919 (1513-1514) [3:395]."

When Kosimkhan refused to help, Sultan Said Khan completely lost his confidence in overcoming the resistance of the Shaybanid Sultans. In April-May 1514, Shaibanids' troops led by the governor of Tashkent, Sevinchkhojakhan, marched to Ferghana Valley. Sultan Said Khan refused to fight and left the valley without a fight. Sultan Saidkhan, who had gone to Kashgar, founded the Saidia state there. 


\section{RESULTS AND DISCUSSIONS}

We believe that it is necessary to study the struggle of Shaybanids and Sultan Saidkhan in two stages in Fergana Valley. The first stage covered 1503-1508. In 1503, the Sheikhbanikhan marched against the troops of the Mongol khan Sultan Mahmud Khan, Ahmad Khan and the Temurid Bobur to help Ahmed Tanbal. Along with Sultan Ahmad Khan, his two sons Sulton Saidkhan and Babajok Sultan also participated in the march. Sultan Saidkhan, who was captured by the allied forces, was taken to Samarkand by Sheibanikhan. When Sheibani Khan began to conquer Khorezm in 1505, Sultan Saidkhan escaped captivity and went to Mongolia to his uncle Sultan Mahmud Khan. Not coming to the agreement with his uncle, he fled to his brother Sultan Khalil. Sultan Khalil and his brother Mansurhon fought against Sultan Saidkhan and won the battle. Sultan Saidkhan, who had no hope, was forced to return to Ferghana Valley. The Shaiban Sultan, who ruled in Ferghana Valley, captured Jonibek Sultan Said Khan. Released from captivity in Fergana, he went to Babur.

The second stage took place in 1509-1514. After the death of Sheibanikhan, the rule of Uzbek sultans in Ferghana was abolished, and the Amirs led by Said Muhammad fought against Shaybanids. The insurgents appealed to Bobur Mirza, who was preparing for the march to Gisar, at this time. Bobur sent Sultan Saidkhan to Ferghana region to take power.

Sultan Saidkhan was captured twice by the Shaybanids after his father's death and every time he managed to survive, he eventually fled to Kabul to appeal to Babur. With the help of Babur he reigned in Ferghana. In 1511-1514 he led the Mongolian army in Ferghana against the Sheybanid Sultans. The defeat of Bobur
Mirzo by Sheybanids in Gijduvan also threatened Sultan Saidkhan's rule in Ferghana. The contacts with the Kazakh Sultan to seek help from Kasymkhan were ineffective. The fact that Sultan Said Khan's army was several times smaller than the army of Sheybani Sultans and the inequality of forces led Sultan Said Khan to leave Mongolia.

\section{CONCLUSION}

In summary, we can see that Sultan Said Khan's struggle with Sultans began in 1503 and lasted until 1514. We would like to emphasize that Sultan Saidkhan fought with Sheybani, Muhammad Sheybanikhan, Jonibek Sultan, Sevinchkhojakhan in Ferghana Valley at the above mentioned stages.

Established in 1511 as a result of fighting the Sheybanids in Ferghana Valley, Sultan Saidkhan's state maintained its existence until 1514, that is, for three years. Its formation was connected with the demise of Sheibanikhan and the efforts of Babur to revert Mawarounnahr from the Shaybanids. The loss of this state was also the result of the defeat of Babur in Gijdivan. Although Sultan Saidkhan's Ferghana state lived for two more years after Babur left Movarounnahr, it was largely due to foreign policy. The loss of the influence of the Kazakh khan Kasimkhan from the north to the Sheybanids state, and Ismail the king of Iran from the south led the Fergana Valley to become a part of Sheybaniy's state peacefully.

\section{REFERENCES}

1. Bartold V.V. Ocherk istorii Semirechya Frunze: Kirgizgosizdat. 1943.

2. Muhammadyor ibn Arab Katag'an. Musaxxir al-bilod /Fors tilidan tarjima, izoxlar va ko'rsatkichlar mualliflari: Ismoil 
Bekjonov, Dilorom Sangirova - T.: Yangi asr avlodi. 2009.

3. Mirzo Muhammad Haydar. Tarix-i Rashidi / Vvedenie, perevod $s$ persidskogo $A$. Urunbaeva, R.P. Djalilovoy, L.M. Epifanovoy, primechaniya i ukazateli R.P. Djalilovoy i L.M. Epifanovoy - T.: Fan. 1996.S. Muhammad Haydar Mirzo Tarixi Rashidiy/ So'z boshi va izoxlar muallifi hamda tarjimonlar V. Raxmonov va Ya, Egamova - T.: Sharq. 2010, B, 357.

4. Muhammad Solih. Shyboniynoma / Tahrir hayati A. Qayumov ba boshqalar; Nashrga tayyorlovchi va so'z boshi muallifi $E$. SHodiev. - T.: Adabiyot va san'at nashriyoti, 1989.

5. Zaxiriddin Muhammad Bobur. Boburnoma. / Nashrga tayyorlovchi P. Shamsiev. - T.: Yulduzcha. 1989.

6. Xofiz Tanish al-Buxoriy. Abdullanoma/ Fors tilidan S. Mirzaev tarjimasi, ilmiy muxarrir, nashrga tayyorlovchi, so'z boshi va izoxdar muallifi akademik B. Axmedov -T.: Sharq. 1999.

7. Azimjonova S.Q. K istorii Fergani vtoroy pol. XV v. Izd-vo AN UzSSR. Tashkent, 1962; Ona je. Gosudarstvo Bobura v Kabule i v Indii. M.: Nauka, 1977.

8. Ahmedov B. Tarixdan saboqlar. - T.: O'qituvchi, 1994. - 430 b.

9. Ahmedov B. O‘zbekiston tarixi manbalari. - T.: O'qituvchi, 2001. - 199 b.

10. Zamonov A. Buhoro xonligida qo'shin tuzilishi va harbiy boshqaruv. - T.: BAYOZ, 2018. - 208 b.

11. Zahiriddin Muhammad Bobur. Boburnoma. / Nashrga tayyorlovchi P. Shamsiev. - T.: Yulduzcha, 1989. - 367 b.

12. Istoriya narodov Uzbekistana. T.2 / pod ped. S.V.Baxrushina. - T.: AN UzSSR, 1947. $-459 b$.
13. Istoriya Uzbekistana (XVI-pervaya polovina XIX v). Otvet redaktor D.A.Alimova. - T.: Fan, 2012. - S. $20-84$.

14. Kamoliddin Binoiy - Shayboniynoma / O'zbekiston tarixi xrestomatiyasi. XVI-XIX asrlar - T.: Fan va texnologiya, 2014. - B. 7 $-12$.

15. Nishonov A. Sulton Saidxon hukmronligi davrida Farg'ona davlati // FarDU ilmiy xabarlari. 2018. - № 2. - B. 50 - 53.

16. Sayfiddin J. Bobirning Farg'ona davlati. T.: Fan, 1995. - 148 b.

17. Yusupova D. Farg‘ona vodiysining XVIXVIII asrlar davri tarixiga oid qo'lyozma asarlari // Farg'ona vodiysi yangi tadqiqotlarda Respublika ilmiy anjuman materiallari. 2012. - B. $122-125$.

18. Usmonov B. Ferghana in the Period of Amir Temur's Struggle for power (13601370). Internotsional Jurnal of Innovative Technology and Exploring Engineering. 2019. Volume - 9, Issuse - 1, November 2019. - P. 3180-3187.

19. Branko Soucek, Svat Soucek. A history of inner Asia. Cambridge University press, 2000. - P. 337.

20. Rene Grousset. The Empire of the Steppes a History of Cental Asia / Translated from the France by Naomi Walford. Retgerts university press. New Jersey, 1970. - P. 653. 